\title{
Mountain forest management in a changing world
}

\author{
Manfred J. Lexer ${ }^{1} \cdot$ Harald Bugmann ${ }^{2}$
}

Published online: 7 November 2017

(C) Springer-Verlag GmbH Germany 2017

Forests in mountain regions are characterized by multiple factors, and processes that are induced by the complex topography, particularly steep ecological gradients. At high elevations, harsh environmental conditions limit productivity, slow down regeneration processes and reduce the number of tree species that are able to thrive, thus rendering mountain forests sensitive to management interventions. Over the twentieth century, climate change has been particularly pronounced in mountain regions, often reaching twice to three times the temperature increase of the global average (Pepin et al. 2015). Further warming is anticipated for the coming decades, and this will strongly affect mountain regions. Productivity will increase as long as water and nutrient supply are not limiting factors (Elkin et al. 2013); competitive relationship between tree species will change (Lindner et al. 2010); and disturbance regimes very likely will intensify (Seidl et al. 2017). Particularly wind and bark beetle disturbances have the potential to severely affect forest structure and composition and thus the delivery of ecosystem services (Temperli et al. 2013; Kulakowski et al. 2017).

Human demands regarding goods and services provided by European mountain forests are diverse and include, among others, intensified biomass utilization in support of wood-based industries; increased interest in nature

Manfred J. Lexer

mj.lexer@boku.ac.at

Harald Bugmann

harald.bugmann@env.ethz.ch

1 Institute of Silviculture, University of Natural Resources and Life Sciences, Vienna (BOKU), Peter-Jordan-Straße 82, 1190 Vienna, Austria

2 Department of Environmental Sciences, Forest Ecology, ETH Zürich, Universitätstrasse 16, 8092 Zurich, Switzerland conservation areas without any management; amenities such as recreation and tourism that rely on a mosaic of different forest types, ages, and structures as well as other land uses such as pastures; and the protection of human assets such as roads and settlements from natural hazards such as rockfall and snow avalanches. However, the share of mountain forests where management is abandoned is increasing in Europe because commercial forestry often is no longer profitable, or new landowners have no interest in forest management. Such developments are highly likely to affect the provisioning of a multitude of these ecosystem services, with partly positive (e.g., more protection from hazards at highest elevations due to new or at least denser forests) but partly also negative consequences (e.g., loss of major timber tree species).

Given these circumstances and often conflicting demands, what is the role of silviculture and forest management in mountain forests so that supply meets the multiple demands for ecosystem services when facing climate change and intensifying disturbance regimes? From 7 to 9 July 2015, more than 130 scientists and forest practitioners met in the Tatra Mountains in Smokovec (Slovakia) to exchange recent research results and discuss possible future approaches to mountain forest management. A set of papers from this conference has been collected for the present Special Thematic Section following after this editorial.

Ponce et al. (2017) used information from forest management plans over several decades to analyze the effects of three silvicultural systems on timber production and stand structural diversity in Scots pine forests (Pinus sylvestris) in the Spanish Central Mountain System. They showed that the expected conflicts between timber production and structural diversity were modulated by the specific implementation of a silvicultural system and by site quality.

Trade-offs and synergies between ecosystem services (ES) were also addressed by Lafond et al. (2017). In stands 
of Silver fir (Abies alba), Norway spruce (Picea abies) and admixed European beech (Fagus sylvatica) in the French Alps, simulation modeling and Pareto frontier techniques were used to explore the relationships between ES indicators for timber production, biodiversity and protection against gravitational hazards. The results revealed strong tradeoffs between timber production and other ES, but synergies between protection and biodiversity.

Norway spruce (P. abies) dominated mountain forests are considered as particularly vulnerable under climate change due to the increasing risk of bark beetle outbreaks. The simulation-based analysis of several management options in Norway spruce forests in the Carpathian Mountains by Hlásny et al. (2017) revealed that neither the currently practiced management nor alternatives proposed by local forest managers and stakeholders were effective in mitigating the negative effects of climate change. Thus, there is scope and a strong need for the derivation of truly alternative management scenarios, and these necessarily need to rely on simulation modeling studies.

Effects of disturbances are also addressed by Wohlgemuth et al. (2017), who synthesized empirical findings on tradeoffs between the recovery of the protection effect against gravitational hazards and the intensity of management interventions from post-disturbance studies in the wake of the storms Vivian (1990) and Lothar (1999).

Large-scale effects of forest management in mountain regions are evaluated in the landscape genetics study on capercaillie (Tetrao urogallus) in the Carpathian Mountains by Klinga et al. (2017). They conclude that targeted management in critical bottleneck habitats is required to maintain viable capercaillie populations.

How different silvicultural cutting patterns affect the provisioning of four different ecosystem services was analyzed by Irauschek et al. (2017). A general finding was that none of the management alternatives performed best for all considered ecosystem services. Small-scale slit and patch cuts appeared as the best compromise alternative. The authors concluded that zoning may improve the efficiency of ecosystem service provisioning.

To support commercial forestry in the future, Silver fir ( $A$. $a l b a$ ) and Norway spruce (P. abies) should be maintained in Dinaric mountain forests. The simulation study by Klopčič et al. (2017) showed that silvicultural measures alone are not sufficient to maintain the two species, but that browsing by ungulates and climate change will reduce the overall share of fir and spruce at regional scale. However, along an elevational gradient contrasting response patterns may occur, thus again emphasizing the need for fine-scale, high-resolution assessments of climate change impacts on mountain forests.

In a warmer climate, disturbance by bark beetles will be a major driver in many conifer-dominated mountain forests. Thus, forest management is facing the challenge to maintain ecosystem service provisioning, and to foster resilience while adapting current mountain forests to future climatic conditions. The papers in this Special Thematic Section indicate that there will be no "one size fits all" management approach. Rather, tailor-made solutions that combine different silvicultural techniques are needed to best meet local requirements.

\section{References}

Elkin C, Gutierrez AG, Leuzinger S, Manusch C, Temperli C, Rasche L, Bugmann H (2013) A $2{ }^{\circ} \mathrm{C}$ warmer world is not safe for ecosystem services in the European Alps. Glob Change Biol 19:1827-1840. doi: $10.1111 / \mathrm{gcb} .12156$

Hlásny T, Barka I, Roessiger J, Kulla L, Trombik J, Sarvašová Z, Bucha T, Kovalčík M, Čihák T (2017) Conversion of Norway spruce forests in the face of climate change: a case study in Central Europe. Eur J Forest Res. doi:10.1007/s10342-017-1028-5

Irauschek F, Rammer W, Lexer MJ (2017) Evaluating multifunctionality and adaptive capacity of mountain forest management alternatives under climate change in the Eastern Alps. Eur J Forest Res. doi: 10.1007/s10342-017-1051-6

Klinga P, Smolko P, Krajmerová D, Paule L (2017) Landscape genetics highlight the importance of sustainable management in European mountain spruce forests: a case study on Western capercaillie. Eur J Forest Res. doi:10.1007/s10342-017-1034-7

Klopčič M, Mina M, Bugmann H, Bončina A (2017) The prospects of silver fir (Abies alba Mill.) and Norway spruce (Picea abies (L.) Karst) in mixed mountain forests under various management strategies, climate change and high browsing pressure. Eur J Forest Res. doi:10.1007/s10342-017-1052-5

Kulakowski D, Seidl R, Holeksa J, Kuuluvainen T, Nagel TA, Panayotov M, Svoboda M, Thorn S, Vacchiano G, Whitlock C, Wohlgemuth T, Bebi P (2017) A walk on the wild side: disturbance dynamics and the conservation and management of European mountain forest ecosystems. For Ecol Manag 388:120-131

Lafond V, Cordonnier T, Mao Z, Courbaud B (2017) Trade-offs and synergies between ecosystem services in uneven-aged mountain forests: evidences using Pareto fronts. Eur J Forest Res. doi:10.1007/ s10342-016-1022-3

Lindner M, Maroschek M, Netherer S, Kremer A, Barbati A, GarciaGonzalo J, Seidl R, Delzon S, Corona P, Kolström M, Lexer MJ, Marchetti M (2010) Climate change impacts, adaptive capacity, and vulnerability of European forest ecosystems. For Ecol Manag 259:698-709

Pepin N, Bradley RS, Diaz HF, Baraer M, Caceres EB, Forsythe N, Greenwood G, Hashmi MZ, Liu XD, Miller JR, Yang DQ (2015) Elevation-dependent warming in mountain regions of the world. Nature Climate Change 5:424-430. doi:10.1038/nclimate2563

Ponce RA, Roig S, Bravo A, del Río M, Montero G, Pardos M (2017) Dynamics of ecosystem services in Pinus sylvestris stands under different managements and site quality classes. Eur J Forest Res. doi:10.1007/s10342-016-1021-4

Seidl R, Thom D, Kautz M, Martin-Benito D, Peltoniemi M, Vacchiano G, Wild J, Ascoli D, Petr M, Honkaniemi J, Lexer MJ, Trotsiuk V, Mairota P, Svoboda M, Fabrika M, Nagel TA, Reyer CPO (2017) Forest disturbances under climate change. Nat Clim Change 7(6):395-402

Temperli C, Bugmann H, Elkin C (2013) Cross-scale interactions among bark beetles, climate change, and wind disturbances: a landscape modeling approach. Ecol Monogr 83:383-402. doi:10.1890/12-1503.1

Wohlgemuth T, Schwitter R, Bebi P (2017) Post-windthrow management in protection forests of the Swiss Alps. Eur J Forest Res. doi:10.1007/s10342-017-1031-x 